Л.І. Цвіркун, С.М. Ткаченко, Л.В. Бешта

\title{
АЛГОРИТМИ ЕНЕРГОЕФЕКТИВНОГО ВИКОРИСТАННЯ ШАХТНИХ ВОДОВІДЛИВНИХ УСТАНОВОК ІЗ ЗАСТОСУВАННЯМ МЕТОДУ ПЕРЕДПІКОВОГО ВМИКАННЯ
}

Анотація. Розглянуто проблему застосування алгоритмів керування насосними агрегатами вугільної шахти при дотриманні методу передпікового вмикання відповідно до графіка навантаження енергосистеми. Виконано аналіз алгоритмів вмикання насосних агрегатів в оптимальному режимі навантаження енергосистеми в залежності від тарифних зон. Обгрунтовано, що в умовах шахти імені М.I. Сташкова доречним є алгоритм керування по трьох точках, що відрізняється високою точністю і надійністю організації роботи водовідливу. Показано, що запропонований алгоритм дозволяє розподілити процес відкачування протягом доби так, щоб результуючі грошові витрати виявилися мінімальними.

Ключові слова: алгоритми, водовідлив, насосний агрегат, енергосистема, метод передпікового вмикання.

Постановка проблеми. Комплекс водовідливу - одне 3 найбільш відповідальних ланок технологічного процесу видобутку вугілля. Приплив шахтних вод відбувається постійно і води необхідно відкачувати навіть в тому випадку, коли не ведеться видобуток корисних копалин. Зупинка насосних агрегатів (НА) внаслідок аварії або інших позаштатних ситуацій може призвести до затоплення шахти. Тому комплекси водовідливу (кількість насосних агрегатів, їх продуктивність, кількість і обсяг водозбірників) розраховуються 3 більш ніж дворазовим запасом [1].

Системи водовідливу вугільних шахт - це потужні споживачі електричної енергії. Частка електроенергії, яка припадає на живлення шахтних водовідливних установок, за різними оцінками становить 20-30\% від загальних річних витрат електричної енергії гірничорудного підприємства. В середньому для шахт Донбасу на 1т видобутого вугілля необхідно відкачати до 1 м³ води [2].

Ефективність водовідливу в значній мірі визначає собівартість кінцевого продукту. При оплаті електроенергії гірничодобувним підприємством по двох-

(C) Цвіркун Л.І., Ткаченко С.М., Бешта Л.В., 2021 


\section{«Системні технологіï» 5 (136) 2021 «System technologies»}

ставковому тарифу істотну частину складає плата за заявлену потужність в години максимуму навантажень в енергопостачальній системі.

Вартість електроенергії змінюється протягом доби згідно регламентуючих документів НКРЕКП. Це дозволяє енергогенеруючим компаніям забезпечити більш рівномірний темп споживання електричної енергії та, таким чином, ефективне використання електроустаткування. Одночасно, наявність накопичувачів шахтних вод дозволяє розподілити процес відкачування протягом доби так, щоб результуючі грошові витрати виявилися мінімальними. Комплекс водовідливу, таким чином, перетворюється на розряд споживачіврегуляторів електроенергії [1].

Аналіз останніх досліджень. В даний час задача енергоефективного використання шахтних водовідливних установок з метою зниження навантаження на енергетичні системи в пікові часи навантаження являє собою важливу науково-практичну задачу, актуальність якої все збільшується. Ї̈̈ вирішенню були присвячені праці багатьох вчених в області осушення родовищ: Праховніка О.В., Разумного Ю.Т., Шевчука С.П., Ященко О.М., Коваля О.М., Паламарчука М. В. і ін. Виконані ними дослідження і розробки являють собою науково-практичну основу для вирішення цієї задачі. В даних роботах розглянуті питання керування енергоспоживанням водовідливних установок, доцільності децентралізованого електропостачання вугільних шахт, а так само запропоновані рішення по формуванню раціонального графіка роботи водовідливних установок.

Метою даної роботи є вибір та обгрунтування алгоритмів автоматизованого передпікового керування насосними агрегатами водовідливу шахти імені M.I. Сташкова с точки зору оптимального режиму навантаження енергосистеми в залежності від тарифних зон.

Виклад основного матеріалу. Нерівномірність споживання електричної енергії викликає збільшення вартості її виробництва і передачі, що в свою чергу, призводить до зростання витрат споживачів енергії.

В даний час енергосистема зобов'язує підприємства знижувати навантаження в години максимуму. Це призводить до певних труднощів при виконанні виробничих планів і зниження техніко-економічних показників діяльності підприємства. Пошуки вирішення даного завдання привели до необхідності введення системи плаваючих тарифів на електроенергію, що стимулюють їі позапікове споживання. При плаваючому тарифі споживач, який зацікавлений в зниженні витрат, вживає заходи до зменшення потужності в 


\section{«Системні технологіï» 5 (136) 2021 «System technologies»}

періоди максимуму навантаження енергосистеми, а в решту часу доби залишається вільним у виборі режиму роботи.

На даний момент для промислових підприємств діють трьохзонні тарифи на електроенергію 3 виділенням тарифних коефіцієнтів для пікової, напівпікової і нічної зон [3].

Одним 3 рішень для зниження загального електроспоживання шахти $€$ виділення споживачів-регуляторів - таких комплексів і ланок технологічного процесу, регулювання графіка роботи яких дозволяє вирівнювати графік навантаження енергосистеми підприємства.

На підприємствах вугільної промисловості заходи щодо створення споживачів-регуляторів зводяться як до організації технологічних процесів відповідно до графіків навантажень енергосистем, так і до повного або часткового відключення енергоємних споживачів на періоди максимуму. До останніх в основному відносяться споживачі з переривчастим режимом роботи, серед яких особливе місце займає шахтний водовідлив.

Організацію роботи водовідливних установок відповідно до графіка навантаження енергосистеми можна здійснювати різними способами керування, можливість і ефективність застосування кожного з яких визначаються конкретними умовами експлуатації.

Виробки шахти ім. M.I. Сташкова пролягають через водоносні горизонти, тому шахта має значний водоприплив (середньогодинне значення - близько $1200 \mathrm{~m}^{3}$ /год). У міру освоєння шахтного поля водоприплив буде збільшуватися.

Комплекс водовідливу шахти складається з центральної насосної камери горизонту -225 м, в якій встановлено 10 насосних агрегатів ЦНС 300×300 (потужність 450 кВт), насосної камери горизонту -300 м, в якій встановлено 5 насосних агрегатів ЦНС (Ш) 300×360 (потужність 560 кВт) і флангових насосних.

Для забезпечення економічно раціонального режиму роботи водовідливних установок (їх зупинки в період максимуму енергосистеми) необхідно, щоб ємність водозбірника вміщала весь приплив води шахти за час максимуму, величина і початок якого встановлюються енергосистемою.

При застосуванні методу передпікового вмикання НА забезпечується повне або часткове звільнення водозбірника від води до початку періоду максимуму навантаження енергосистеми, чим створюються умови для позапікового споживання електроенергії [5]. Метод вимагає, щоб був звільнений такий об’єм водозбірника, який гарантовано не призведе до переповнення, незважаючи на 


\section{«Системні технології» 5 (136) 2021 «System technologies»}

коливання притоку у діапазоні, притаманному умовам гірничої виробки, а у даному випадку - умовам виробок шахти ім. М.І. Сташкова.

У випадку застосування такого методу передпікове керування насосними агрегатами може здійснюватися різними алгоритмами в залежності від необхідної точності звільнення водозбірника до початку періоду максимуму, а саме:

- примусовим включенням з подальшим регулюванням подачі установки;

- керуванням по трьох точках;

- примусовим включенням за часом.

Розглянемо докладніше наведені способи.

Алгоритм примусового включення 3 подальшим регулюванням швидкості відкачування води. Повне або часткове звільнення водозбірника до моменту початку періоду максимуму навантаження енергосистеми може досягатися шляхом примусового вмикання насосних агрегатів в період, що передує періоду максимуму. 3 рис. 1 видно, що для повного звільнення водозбірника $\mathrm{V}_{\text {мін }}$ до початку періоду максимуму $t_{m}$ слід провести примусове вмикання насосного агрегату в момент часу $t_{1}$ або в момент $t_{1}{ }^{\prime}$ для графіка, показаного штриховими лініями. Припустимо, що закон зміни об'єму води в водозбірнику при працюючій водовідливній установці відомий і заданий лінією АВ (рис. 1). Якщо поєднати кінець цієї лінії з початком періоду максимуму навантаження енергосистеми, то її ординати можна вважати заданими значеннями обсягу води в водозбірнику в часі в передпіковий період. При досягненні фактичним обсягом води обсягу, заданого лінією АВ (точка С), слід провести примусове вмикання водовідливної установки, після чого (якщо фактичний закон зміни об'єму води відповідає заданому лінією АВ) водозбірник повністю звільняється до початку періоду максимуму навантаження.

Алгоритм досить простий з точки зору автоматизації, але в умовах шахти iм. M.I. Сташкова неприйнятний через слабку прогнозованість коливань притоку [5]. Це унеможливлює точні розрахунки моментів $t_{1}$ i $t_{1}^{\prime}$ у процесі застосування засобів автоматизації. 
«Системні технології» 5 (136) 2021 «System technologies»

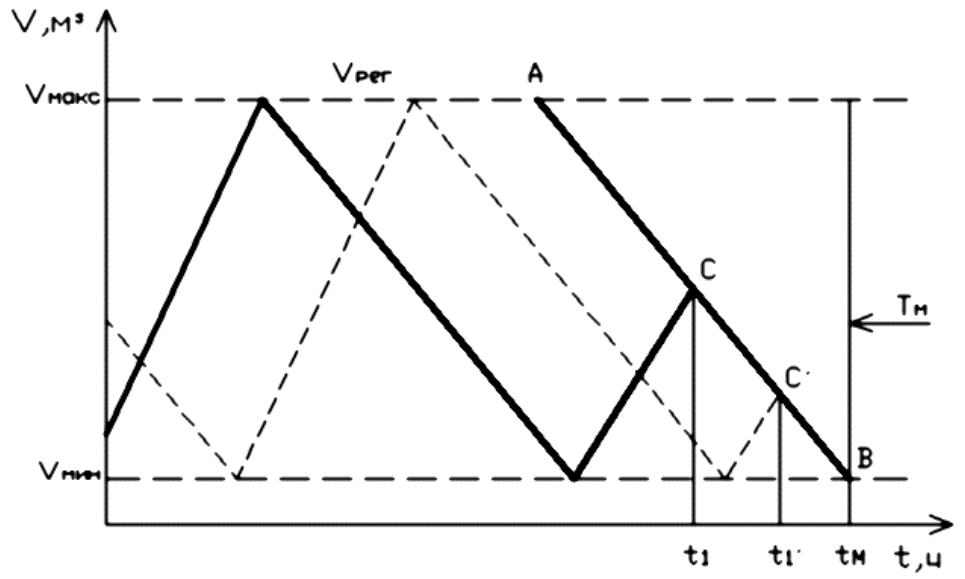

Рисунок 1 - Організація роботи водовідливної установки при проходженні максимумів навантажень

Алгоритм керування водовідливом по трьох точках. При постійних значеннях припливу води і продуктивності установки для повного звільнення водозбірника від води до початку періодів $T_{м 1}, T_{м 2}$ максимуму навантаження енергосистеми (рис. 2), слід примусово вмикати водовідливну установку в визначені моменти часу $t_{1}$ i $t_{5}$, які при заданих умовах не змінюють свого положення з доби в добу.

При заданому алгоритмі керування перед кожним періодом максимуму навантаження енергосистеми визначається місцезнаходження на осі часу точки С (момент досягнення нижнього рівня водою в водозбірнику за умови, що $\left.t_{m}-t_{4}<T u\right)$, після чого період часу $T u^{\prime}=t_{m}-t_{4}$, укладений між точками $C$ i $E$, ділиться на $k$ частин, де $k$ визначається як відношення Тu до Тз. Після закінчення отриманого значення часу з моменту, відповідного точці С, проводиться примусове вмикання установки (точка $D$ ) автоматично (при наявності спеціального пристрою) або дистанційно диспетчером.

3 метою підвищення точності функціонування системи при змінах припливу i подачі насосної установки, визначення величини коефіцієнта $k$ доцільно проводити перед кожним періодом максимуму навантаження енергосистеми.

Розглянутий алгоритм вигідно відрізняється від попереднього тим, що, за рахунок незначного ускладнення підходу, об’єм води у водозбірнику утримується у межах прогнозованого. Тому останнє передпікове вмикання $є$ окремим випадком, що відповідає способу 1, але тут гарантується виконання умови методу щодо звільнення необхідного об’єму водозбірника за рахунок 
«Системні технології» 5 (136) 2021 «System technologies»

досягнення прогнозованого об’єму води перед останнім передпіковим вмиканням.

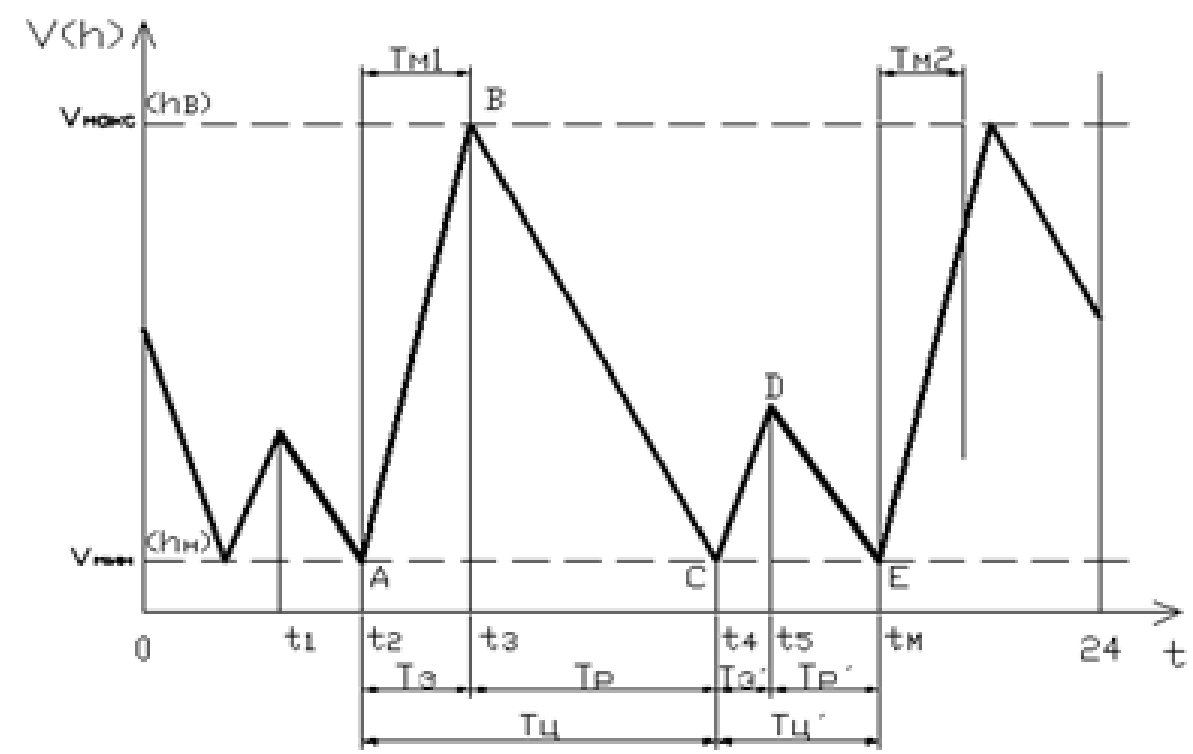

Рисунок 2 - Організація роботи водовідливної установки при керуванні по трьох точках, де Tu і Tu’ - тривалість відповідно повного і передпікового циклів роботи водовідливної установки; Тз і Тз'- тривалість відповідно заповнення водозбірника в повному і передпіковому циклах;

$T p$ i $T p^{\prime}$ - час продуктивної роботи насосного агрегату відповідно в повному і передпіковому циклах

Алгоритм примусового вмикання за часом. Принцип дії такого алгоритму керування заснований на тому, що при одному і тому ж моменті примусового вмикання водовідливної установки існує два значення припливу води $Q_{1}$ i $Q$, при яких система функціонує безпомилково в режимі регулятора навантаження енергосистеми. Цим значенням притоку (рис. 3) відповідають графіки $1 \mathrm{i} 2$. В період максимуму навантаження $T_{\text {м1 }}$ водозбірник заповнюється, потім в момент часу $t_{2}$ незалежно від рівня води в водозбірнику вмикається насосний агрегат, звільняючи водозбірник. Після цього водозбірник знову заповнюється, в момент часу $t_{4}$ установка вмикається примусово і відкачує воду до початку періоду максимуму навантаження. Значення моменту часу $t_{4}$ обирається один раз і зберігається постійним щодоби.

В силу сталості відміток часу $t_{4} \mathrm{i} t_{m}$ час роботи водовідливної установки в передпіковий період $T_{p}$ в даному випадку залишається постійним. 
«Системні технології» 5 (136) 2021 «System technologies»

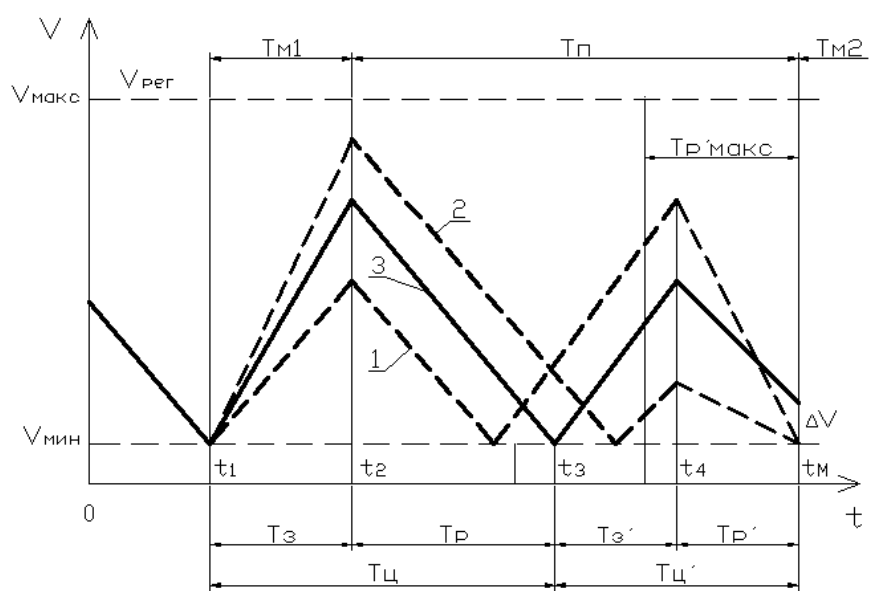

Рисунок 3 - Організація роботи водовідливної установки при вмиканні за часом, де Tu i Tú ' - тривалість відповідно повного і передпікового циклів роботи водовідливної установки; Тз і Тз' - тривалість відповідно заповнення водозбірника в повному і передпіковому циклах; Tp і $T p^{\prime}$ - час продуктивної роботи насосного агрегату відповідно повному і передпіковому циклах;

$T n$ - період провалу в графіку навантаження енергосистеми

Даний алгоритм рекомендовано для застосування в умовах маловодних шахт або для керування допоміжним водовідливом, якому притаманні відносно невеликі зміни припливу води і малі гідравлічні потужності [5]. 3 цих причин, не дивлячись на порівняну простоту, в умовах шахти ім. М.I. Сташкова спосіб неприйнятний.

Висновки. За результатами порівняльного аналізу алгоритмів автоматизованого керування водовідливом з урахуванням періодів максимуму навантаження енергосистеми можна в якості основного способу реалізації методу передпікового вмикання водовідливу рекомендувати спосіб керування водовідливом по трьох точках. Його порівняна складність нівелюється саме застосуванням програмованих засобів автоматичного керування.

\section{ЛIТЕРАТУРА / ЛИТЕРАТУРА}

1. Повышение энергоэффективности при эксплуатации комплекса шахтного водоотлива / Д.А.Бешта, А.В.Балахонцев // Проблеми розвитку впровадження інформаційних технологій у наукову та інноваційну сфери освіти. - 2014. C. $22-24$

2. Разумный Ю. Т. Повышение энергоэффективности главной водоотливной установки угольной шахты / Ю. Т. Разумный, Н. Ю. Рухлова, А. В. Рухлов // Нау- 


\section{«Системні технологіï» 5 (136) 2021 «System technologies»}

ковий вісник Національного гірничого університету. - 2013. - № 5. - С. 67-72. Режим доступу: http://nbuv.gov.ua/UJRN/Nvngu_2013_5_13.

3. Про тарифи, диференційовані за періодами часу: Постанова Національної комісії регулювання електроенергетики України № 1241 від 20.12.2001 (Редакція станом на 01.01.2019).

4. Ященко А.М., Коваль А.Н., Паламарчук Н. В., Антонов Э.И. Перспективы развития техники и технологии шахтного отлива.//Уголь Украины, №11, 1997 г. c. $21-25$.

5. Данильчук, Г. И. Автоматизация электропотребления водоотливных устанвок/ Г. И. Данильчук, С. П. Шевчук, П. К. Василенко. - К.: Техника, 1981. - 102 с.

6. Праховник А.В. Автоматизация управления электропотреблением: Вища школа, Киев, 1986, с.76.

7. Единые правила безопасности при разработке рудных, нерудных и россыпных месторождений полезных ископаемых подземным способом. Електроний ресурс. Режим доступу: http://www.snip-info.ru/Pb_06-111-95.htm

\section{REFERENCES}

1. Povyishenie energoeffektivnosti pri ekspluatatsii kompleksa shahtnogo vodootliva / D.A.Beshta, A.V.Balahontsev // Problemi rozvitku vprovadzhennya InformatsIynih tehnologIy u naukovu ta InnovatsIynu sferi osviti. - 2014. - S. 22-24.

2. Razumnyiy Yu. T. Povyishenie energoeffektivnosti glavnoy vodootlivnoy ustanovki ugolnoy shahtyi / Yu. T. Razumnyiy, N. Yu. Ruhlova, A. V. Ruhlov // Naukoviy vIsnik NatsIonalnogo gIrnichogo unIversitetu. - 2013. - \# 5. - S. 67-72. Rezhim dostupu: http://nbuv.gov.ua/UJRN/Nvngu_2013_5_13.

3. Pro tarifi, diferentsiyovani za periodami chasu: Postanova Natsionalnoyi komisiyi regulyuvannya elektroenergetiki Ukrayini \# 1241 vid 20.12.2001 (Redaktsiya stanom na 01.01.2019).

4. Yaschenko A.M., Koval A.N., Palamarchuk N. V., Antonov E.I. Perspektivyi razvitiya tehniki i tehnologii shahtnogo otliva.//Ugol Ukrainyi, \#11, 1997 g. - s. 21 - 25

5. Danilchuk, G. I. Avtomatizatsiya elektropotrebleniya vodootlivnyih ustanvok/ G. I. Danilchuk, S. P. Shevchuk, P. K. Vasilenko. - K.: Tehnika, 1981. - 102 s.

6. Prahovnik A.V. Avtomatizatsiya upravleniya elektropotrebleniem: Vischa shkola, Kiev, 1986, s.76.

7. Edinyie pravila bezopasnosti pri razrabotke rudnyih, nerudnyih i rossyipnyih mestorozhdeniy poleznyih iskopaemyih podzemnyim sposobom. Elektroniy resurs. Rezhim dostupu: http://www.snip-info.ru/Pb_06-111-95.htm 


\section{«Системні технології» 5 (136) 2021 «System technologies»}

\section{Алгоритмы энергоэффективного использования шахтных водоотливных}

установок с применением метода передпикового включения

Рассмотрена проблема применения алгоритмов управления насосными агрегатами угольной шахты при соблюдении метода передпикового включения в соответствии с графиком нагрузки энергосистемы. Выполнен анализ агоритмов включения насосных агрегатов в оптимальном режиме нагрузки энергосистемы в зависимости от тарифных зон. Обосновано, что в условиях шахты имени Н.И. Сташкова уместным является алгоритм управления по трем точкам, отличающийся высокой точностью и надежностью организации работы водоотлива. Показано, что предложенный алгоритм позволяет распределить прочесс откачки в течение суток так, чтобы результирующие денежные расходы оказались минимальными.

\section{Algorithms for energy efficient use of mine drainage plants using before the peak method}

The article deals with the problem of using algorithms for controlling the pumping units of a coal mine while observing the method of peak switching in accordance with the load schedule of the power system. It is noted that a mine stepped drainage is a complex hydraulic complex, the pumps of which pump mine water from one horizon to another horizon and then to the surface of the mine. Electric drives for mine drainage units are one of the largest consumers of electricity in the mining and metallurgical complex. These parameters are among the most powerful and critical links of technological equipment, the operation of which determines the level of energy consumption and the safety of work in the extraction of minerals. The total capacity of pumping units is on average $20-30 \%$ of the total annual consumption of electrical energy of a mining enterprise and drainage units have a work schedule independent of the extraction technology during the day. Therefore, drainage pumping units can act as consumersregulators in the power supply system of the enterprise, turning them on or off can reduce the declared capacity of the enterprise, as well as the unevenness of the load schedule of the power system.

The article describes the algorithms for automated control of the drainage pumping unit, taking into account the "peak" loads in the mine power supply system. These include: Forced On Time Algorithm With Subsequent Feed Control, Three Point Control Algorithm And Forced On Time Algorithm. Based on the results of a comparative analysis of algorithms for automated control of drainage, taking into account the periods of maximum load of the power system, it is reasonable that in the conditions of the mine named after M.I. Stashkov, a three-point control algorithm is appropriate, characterized by high accuracy and reliability of the organization of the drainage operation. It is shown that the proposed method allows you to distribute the pumping process during the day so that the resulting cash costs are minimal. 
«Системні технологіï» 5 (136) 2021 «System technologies»

Цвіркун Леонід Іванович - к.т.н., професор кафедри інформаційних технологій та комп’ютерної інженерії Національного технічного університету «Дніпровська політехніка» (м. Дніпро).

Бешта Лілія Валеріївна - асистент кафедри інформаційних технологій та комп’ютерної інженерії Національного технічного університету «Дніпровська політехніка» (м. Дніпро).

Ткаченко Сергій Миколайович - к.т.н., доцент кафедри інформаційних технологій та комп’ютерної інженерії Національного технічного університету «Дніпровська політехніка» (м. Дніпро).

Цвиркун Леонид Иванович - к.т.н., профессор кафедры информационных технологий и компьютерной инженерии Национального технического университета «Днепровская политехника» (г. Днепр).

Бешта Лилия Валериевна - ассистент кафедры информационных технологий и компьютерной инженерии Национального технического университета «Днепровская политехника» (г. Днепр).

Ткаченко Сергей Николаевич - к.т.н., доцент кафедры информационных технологий и компьютерной инженерии Национального технического университета «Днепровская политехника» (г. Днепр).

Tsvirkun Leonid - candidate of technical science, professor of department of information technologies and computer engineering of the National technical university "Dneprovskaya polytechnika", Dnipro, Ukraine.

Beshta Liliia - assistant of department of information technologies and computer engineering of the National technical university "Dneprovskaya polytechnika", Dnipro, Ukraine.

Tkachenko Sergey - candidate of technical science, assistant professor of department of information technologies and computer engineering of the National technical university "Dneprovskaya polytechnika", Dnipro, Ukraine. 